\title{
METODE PROMOSI MELALUI DIRECT SELLING DALAM MENINGKATKAN MINAT KONSUMEN MENGGUNAKAN JASA HOTEL
}

\author{
PROMOTION METHOD AS DIRECT SELLING ON INCREASING THE INTEREST OF CONSUMERS \\ USING THE SERVICE HOTEL
}

\author{
EV Hanifah1, Sukarelawati², Agustini ${ }^{3 a}$ \\ 1,2,3 Jurusan Ilmu Komunikasi, Fakultas Ilmu Sosial dan Ilmu Politik, Universitas Djuanda \\ Jl. Tol Ciawi No.1 Kotak Pos 35 Bogor 16720.
}

a Korespondensi: Agustini, E-mail: tiniagustin1964@gmail.com

(Diterima: 20-02-2017; Ditelaah: 27-3-2016; Disetujui: 28-03-2017)

\begin{abstract}
The purpose of the studied: (1) To find out how promotion through direct selling, in increasing the interest of consumers using the services of Grand Cempaka hotel Puncak Bogor. This research used descriptive qualitative method by doing data retrieval technique and interview and direct observation. The validity of the data performs triangulation techniques. Technique data analyst in this research that was by reducing data, presenting data, and take conclusion from data obtained. Promotion through good direct selling by representative sales people was communicating well with potential customers, involving direct personal interaction between a potential buyer and sales exsexutif Promotion. This research approach using qualitative approach, The research method used was descriptive qualitative research method In this study, using two types of informants, data collection techniques were direct in-depth observation and direct interviews. Results Discussion of promotions conducted for easy sales promotion executives, making product Presentation, speed (speed) promotion, how quickly to be understood by prospective customers, In the process of promotion through direct selling Conclusion Product Presentation Grand Cempaka Hotel were not perform preparation stage during promotion because promotion was a direct selling promotion that was directed sales by way of personal communication with sales and prospective buyers, so that sales can adapt to the existing situation within the company to match the information needs of each potential buyer. Adding Human Resources (HR) to division Sales section, the division's efforts to help when doing promotion with sales promotion executives, to produce.
\end{abstract}

Keywords: Method of promotion direct selling, consumer, hotel

\begin{abstract}
ABSTRAK
Tujuan penelitian : (1) Untuk mengetahui bagaimana promosi melalui direct selling, dalam meningkatkan minat konsumen menggunakan jasa hotel Grand Cempaka Puncak Bogor. Penelitian ini menggunakan metode deskriptif kualitatif dengan melakukan teknik pengambilan data dan wawancara dan observasi langsung. Keabsahan data melakukan teknik triangulasi. Teknik analis data dalam penelitian ini yaitu dengan mereduksi data, menyajikan data, dan mengambil kesimpulan dari data yang diperoleh. Promosi melalui direct selling yang baik oleh tenaga penjual yang representatif yaitu melakukan komunikasi yang baik dengan calon konsumen, melibatkan interaksi personal langsung antara seorang pembeli potensial dengan sales exsexutif Promotion. Pendekatan penelitian ini menggunakan pendekatan kualitatif. Metode penelitian yang digunakan adalah metode penelitian
\end{abstract}


deskriptif kualitatif Pada penelitian ini, menggunakan dua jenis informan, teknik pengumpulan data yaitu observasi langsung secara mendalam serta wawancara langsung. Hasil Pembahasan promosi dilakukan agar mudah sales promotion eksekutif, melakukan Penyajian produk, kecepatan (speed) promotion, seberapa cepat agar dipahami oleh calon konsumen, Pada Proses promosi melalui direct selling Kesimpulan Penyajian Produk Grand Cempaka Hotel tidak melakukan tahapan persiapan saat promosi karena promosi yang dilakukan adalah promosi direct selling yaitu penjualan langsung dengan cara komunikasi personal dengan sales dan calon pembeli, Sehingga sales mampu mengadaptasi terhadap keadaan yang ada didalam perusahaan agar sesuai dengan kebutuhan informasi setiap pembeli potensial. Menambah Sumber Daya Manusia (SDM) untuk divisi Sales section, upaya divisi tersebut agar membantu saat melakukan promotion bersama sales promotion eksekutif, agar menghasilkan

Kata kunci : Metode promosi direct selling, konsumen, hotel

EV Hanifah, Sukarelawati, Agustini 2017. Metode Promosi Melalui Direct Selling Dalam Meningkatkan Minat Konsumen Menggunakan Jasa Hotel. Jurnal Komunikatio. 47-60. 


\section{PENDAHULUAN}

Dewasa ini persaingan dunia bisnis pada beberapa dekade terakhir semakin ketat dalam bidang objek pariwisata seperti perhotelan. Setiap perusahaan dituntut untuk memiliki perencanaan strategi yang unggul dan komprehensif. Sehingga perusahaan jasa perhotelan perlu memikirkan strategi hotel agar dapat mempertahankan eksistensinya. Perkembangan bisnis dikawasan puncak sangat berpengaruh dalam dunia pariwisata, sehingga muncul perusahaan dibidang jasa perhotelan untuk berperan dalam bisnis yang sedang pesat pertumbuhanya. Kabupaten Bogor yang berada dikawasan puncak sebagai salah satu kawasan pariwisata memiliki pertumbuhan yang cukup pesat dalam beberapa tahun terakhir.Jalan Raya Puncak Cipayung, menjadi jalur bisnis utama di Kabupaten Bogor setelah berdirinya berbagai macam Restoran, Factory outlet, Hotel, Ruko dan bangunan bisnis lainya.

Persaingan bisnis di bidang jasa perhotelan di Puncak Bogor semakin meningkat, seperti hotel bintang 3 jumlahnya lebih banyak dibandingkan hotel kelas bintang lainya. Saat ini dikawasan Puncak Bogor banyak bermunculan hotel-hotelbaru, kebutuhan dan keinginan pengunjung semakin berkembang. Hal ini mendorong perusahaan untuk berusaha meningkatkan kualitas atau kuantitas produk hotel, serta fasilitas dan pelayanan yang diberikan Grand Cempaka Hotel.

Grand Cempaka Hotel berusaha memberikan nilai tambah yang berbeda seperti penawaran disconpada saat harihari weekand dan libur nasional, serta memberikan pelayanan yang excelent terutama bagi yang memiliki member.Hal ini dimungkinkan pengunjung memiliki alasan sendiri memilih Grand Cempaka Hotel Puncak Bogordibandingkan dengan hotel lainnya. Dalam bisnis perhotelan ada banyak hal yang dapat ditawarkan kepada calon konsumen, semua yang ditawarkan adalah produk hotel. Produk tersebut dapat dibagi dalam beberapa bentuk seperti kamar hotel (room), Pelayanan makanan dan minuman (food \&beverage), restourant, aula, mesjid, ruang pertemuan, bar,atau night club. Tidak terkecuali Grand Cempaka Hotel yang menawarkan semua produk tersebut.

Peningkatan Konsumen melibatkan interaksi antara pengaruh dan kognisi. Untuk memahami konsumen, pemasar yang tepat harus memahami apa yang konsumen pikirikan (kognisi). Konsumen untuk melakukan pembelian dapat dipengaruhi oleh lingkungan yang meliputi faktor budaya, faktor kelas sosial, faktor pengaruh pribadi, faktor keluarga, dan faktor situasi. Pengaruh peningkatan konsumen dilakukan dengan cara pendekatan interpretif, pendekatan ini menggali secara mendalam konsumen dan hal yang mendasarnya.

Hotel menjual jasa melalui strategi promosi. Promosi pada dasarnya adalah membangun sebuah produk dibenak konsumen. Bertujuan untuk memperkenalkan produk hotel sekaligus berusaha untuk menarik minat konsumen dalam menggunakan jasa dan membeli produk hotel tersebuat. Dalam promosi hotel,banyakcara yang dilakukan, salah satunya direct selling memiliki keistimewan berinteraksi dengan pembeli guna menjawab pertanyaan-pertanyaan dan mengatasi penolakan dan menargetkan pembeli (Wiliam 1991). 
Menurut Efi (2016) bahwa promosi melalui direct selling di Grand Cempaka Hotel Puncak Bogor merupakan interaksi tatap muka langsung dengan satu atau lebih. Calon pembeli untuk meyakinkan pembelian ulang jasa perhotelan. sales promotion exsekutifGrand Cempaka Hotel Puncak Bogor menawarkan produknya seperti kamar tidur (room), makanan \& minuman (food \& beverage), restaurant, ruangan pitnes,ruang pertemuan, kolam renang, mesque, dan club atau bar.

Efi menambahkan, peran sales promotion exsekutifGrand Cempaka Hotel Puncak Bogor pada promosi derict selling adalah menjual, mengajak, memberitahu, dan mengingatkan kembali semua produk dan fasilitas yang dimiliki oleh hotel. Tugas pokok sales promotion exsekutif dalam kesehariannya memasarkan jasa hotel melalui tatap muka langsung (face to face). Pada saat menawarkan jasa hotel yang didukung dengan media telepon. Kegiatan promosi dalam direct selling, berupaya memberikan rangsangan pesan yang bergairah pada pengunjung yang dimungkinkan pengunjung akan membandingkan pilihan dari pesaing hotel tersebut. Seiring dilakukanya kegiatan promosi melalui penjualan langsung (direct selling) diharapkan calon pelanggan akan membeli jasadan menemukan keunggulan jasa perhotelan yang ditawarkan perusahaan tersebut. Direct selling lebih banyak menekankan aspek kegiatan promosi berulang-ulang dan menawarkan kemudahan dalam pembeliaan kepada calon konsumen. Kemudahan tersebut dengan cepatnya calon konsumen membeli produk jasa kepada sales promotion melalui direct selling, untuk lebih cepat menikmati fasilitas yang diberikan Grand Cempaka Hotel Puncak Bogor tersebut.
Survei Marketing Grand Cempaka Hotel tahun 2015-2016 membuktikan bahwa kebanyakan pengunjung Grand Cempaka Hotel Puncak Bogor datang dan menginap karena adanya suatu event khusus, seperti hari raya besar, atau libur nasional. Salah satu bentuk promosi yang menjadi favorit bagi Grand Cempaka Hotel yaitu promosi direct selling.

Adanya peningkatan jumlah rata-rata sebesar 60\% pengunjung Grand Cempaka Hotel Puncak Bogor dari tahun 2014-2015 sampai 2016, merupakan fenomena yang patut diteliti. Peningkatkan jumlah konsumen di Grand Cempaka Hotel Bogor tersebut disebabkan adanya kegiatan promosi direct selling padake empat bauran promosi yang ada yaitu produk (product), harga (price),tempat (place), promosi (promotion).Empat bauran tersebut berupa produk jasa seperti fasilitas bungalow dan room serta fasilitas lainya, tempat yang disediakan oleh promosi dan tempat fasilitas hotel, Grand Cempaka Puncak Bogor melakukan promosi dengan melalui direct selling untuk meningkatkan minat konsumen menggunakan jasa hotel Grand Cempaka Puncak Bogor.

Dalam penelitian terdahulu yang ditulis oleh Nur Tahun (2010), dengan judul bahwa Strategi Promosi Direct Sellingdalam meningkatkan hotel Horison bekasi Terhadap Jumlah Pengunjung 2014. Teori yang di gunakan adalah teori SMCRE yaitu Source, Message, Channel, Receiver, Effect. Metode penelitian yang digunakan dalam penelitian ini adalah metode survei. Dengan proses pengumpulan data menggunakan kuisioner, wawancara, dan dokumentasi langsung denganmarketing Hotel Horison Bekasi. Temanya menerangkan bahwa promosi direct selling ialah promosi yang dilakukan 
secara tatap muka langsung, berpengaruh padaefect yang cepat, dalam melakukan promosi melalui direct selling tersebut.

Promosi dilakukan oleh salah satu sales promotion exsexutif atau marketing Hotel Horison Bekasi, dengan melakukan penawaran di tempat perusahaan (Hotel) atau diluar. Sales promotion exsekutif melakukan promosi Direct Sellingsehingga berupaya meningkatkan konsumen secara luas dan memudahkan konsumen secara penawaran harga. Tamu bisa lebih mengetahui fasilitas yang dilakukan dan diberikan oleh hotel secara langsung. Hal ini berbeda dengan promosi sejenis lainya, promosi yang dilakukan ini tidak begitu cukup besar dalam pengeluaran Hotel Harison Bekasi. Dalam penelitian sebelumnya sudah dijelaskan bahwa promosi yang dilakukan Melalui direct selling sangat menguntungkan bagi perusahaan begitu pula dengan minat konsumen Hotel Harison Bekasi.

Menurut Dewantri (2014). Dengan judul startegi promosi melalui direct selling "Cafe burger lovers me" dalam meningkatkan jumlah konsumen, bertujuan menggambarkan startegi komunikasi yang dilakukan di cafe burger lovers me dalam menigkatkan jumlah konsumennya sehingga dapat lebih dikenal dan memiliki citra khas sendiri. Kemudian teori yang digunakan adalah teori bauran pemasaran yang terdiri dari 4P yaitu produk, (product) harga, (price) tempat, (place), promosi, (promotions). Dengan menggunakan promosi penjualan langsung di cafe burger lovers me, peneliti tertarik untuk meneliti topik ini karena adanya promosi yang dilakukan secara langsung atau direct selling dengan mudah dan cepat, melakukan penawaran di tempat, menggunakan bauran pemasaran serta calon konsumen lebih praktis guna dalam melakukan pembelian di cafe burger lovers me. Hal tersebut membuktikan bahwa promosi direct selling sangat berpengaruh dalam cafe burger lover me, terutama dalam menarik minat pelanggan. Hal ini dengan mudahnya serta cepat menarik konsumen, tidak memerlukan biaya yang cukup besar untuk melakukan promosi melalui direct selling di cafe burger lover me. Peneliti tertarik untuk meneliti judul tersebut melihat keunggulan yang di milikinya, terutama promosi direct selling yang digunakan oleh cafe burger lovers me tersebut. Sehingga dimungkinkan pula dapat diamati pada upaya promosi melalui direct selling di Grand Cempaka Puncak Bogor. Adapun secara kualitatif dimaksudkan bahwa penelitian akan menggali secara mendalam bagian bauran promosi melalui direct selling yang dilakukan oleh sales promotion Grand Cempaka Hotel Puncak Bogor sehingga dapat dilihat dari strategi komunikasi yang dilakukan oleh Grand Cempaka Hotel dalam menyampaikan isi pesan sehingga dapat menarik minat konsumen menggunakan jasa hotel.

Promosi melalui direct selling yang baik oleh tenaga penjual yang representatif yaitu melakukan komunikasi yang baik dengan calon konsumen, melibatkan interaksi personal langsung antara seorang pembeli potensial dengan sales exsexutif Promotion. Direct seling dapat menjadi promosi yang hebat melalui komunikasi personal dengan sales promotion exsekutifsehingga dapat meningkatkan keterlibatan konsumen dengan jasa perhotelan yang ditandai dengan proses pengambilan keputusan konsumen. Hal inimenunjukan konsumen dimungkinkan dapat lebih termotivasi untuk masuk dan 
memahami informasi yang di sajikan oleh sales promotion tentang suatu produk jasa. Situasi komunikasi interaktif memungkinkan sales beradaptasi dengan kebutuhan informasi bagi setiap pembeli potensial. Berdasarkan dari latar belakang diatas, penulis merumuskan masalah sebagai kajian penelitiansebagai berikut; Bagaimana Promosi melalui direct selling di Grand Cempaka Puncak Bogor dalam meningkatkan minat konsumen?. Penelitian bertujuan untuk mengetahui promosi melalui direct selling, di Grand Cempaka Puncak Bogor dalam meningkatkan minat konsumen.

\section{Kerangka Pemikiran Penelitian}

Penelitian ini, dapat dilihat dari kerangka operasional, pada bagan dibawah ini Grand Cempaka Hotel memiliki promosi melalui direct selling yang dipromosikan oleh pihak marketing dan sales promotion Grand Cempaka Hotel Puncak Bogor.

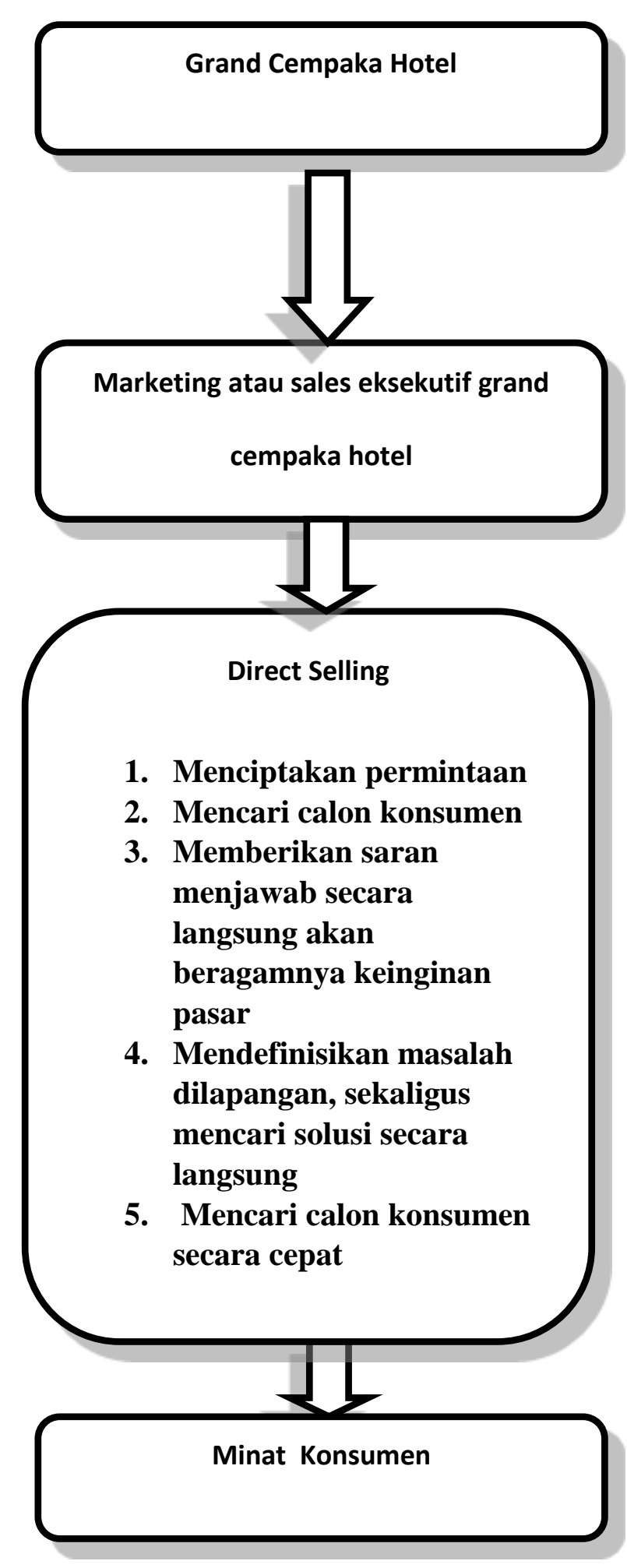

Gambar 1. Kerangka Berfikir Penelitian 


\section{METODE PENELITIAN}

Penelitian ini menggunakan pendekatan penelitian kualitatif menurut Deddy Mulyana (2001) metode penelitian kualitatif ini dibedakan dengan metode penelitian kuantitatif dalam arti metode penelitian kualitatif tidak mengandalkan bukti berdasarkan logika matematis, prinsip angka atau metode statistik. Pembicaraan yang sebenarnya, isyarat, dan tindakan sosial lainnya adalah mental untuk analisis kualitatif. Metode penelitian kualitatifyang digunakan penelitian karena topik atau masalah membutuhkan studi penelitiandeskriptif, menyeluruh, terperinci, dan menghasilkan analis mendalam dengan cara pengumpulan detail informasi menggunakan berbagai macam prosedur dan sumber data kualitatif study dengan kata lain multi sumber bukti, penelitian juga bersifat menjawab pertanyaan bagaimana, mengapa, dan apa hasilnya (Sukmadinta,2011).

Lokasi Penelitian dibagian Marketing Grand Cempaka Hotel Puncak Bogor yang beralamat di jalan Raya Puncak Km 17 Cipayung Puncak Bogor-Jawa Barat. Www.Grandcempaka.co.id.com.

Metode penelitian yang digunakan adalah metode kualitatif, penelitian deskriptif kualitatif bertujuan untuk mendeskripsi, menafsirkan data yang bersangkutan dengan situasi yang sedang terjadi yang saat didalamnya terdapat upaya mendeskripsikan, mencatat, analisis dan menginterpretasikan kondisi yang sekarang ini terjadi atau ada. Dengan kata lain penelitian deskriptif kualitatif bertujuan untuk memperoleh informasiinformasi mengenai keadaan yang ada. Bahwasanya penelitian deskriptif kualitatif dirancang untuk mengumpulkan informasi tentang keadaan-keadaan atau situasi yang sekarang yang sedang berlangsung. Pada hakikatnya penelitian deskriptif kualitatif adalah suatu metode dalam meneliti status sekelompok manusia, suatu objek dengan tujuan membuat deskriptif, gambaran atau lukisan secara sistematis, factual dan akurat mengenai fakta-fakta atau fenomena yang diselidiki.

Pada penelitian ini, menggunakandua jenis informan. Informan pertama adalah wawancara dengan pihak menager Marketing, sales exsekutif promotion,mengenai promosi direck selling dalam meningkatkan minat konsumen menggunakan jasa perhotelan.Informan kedua pihak konsumen Hotel Grand Cempaka Puncak Bogor, yaitu Bapak Adi septiadi guna mengetahui informasi pembelian secara langsung.

Analisis data adalah proses mencari dan menyusun secara sistematis data yang diperoleh dari hasil wawancara, catatan lapangan, dan bahan-bahan lain, sehingga dapat mudah difahami, dan temuanya dapat diinformasikan kepada orang lain (Sugiyono, 2010). Dalam penelitian kualitatif, data diperoleh dari berbagai sumber, dengan menggunakan teknik pengumpulan data yang bermacammacam, dan dilakukan secara terusmenerus sampai datanya jenuh. Dalam prosesnya, penelitian ini menggunakan model interaktif yang dikembangkan oleh (Miles dan Huberman 2010) yang meliputi data reduction (reduksi data), datadisplay(penyajian data)danconclusion drawing/verification. Selanjutnya model interaktif dalam analisis data ditunjukkan pada Gambar 2. 


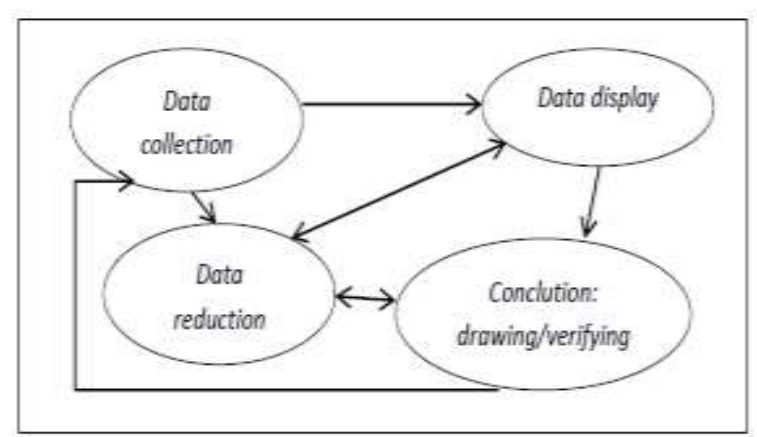

Gambar 2 Proses Analisa Data

\section{HASIL DAN PEMBAHASAN}

Sejak berdirinya hotel Grand cempaka Puncak Bogor, sebagai salah satu hotel bintang 3, yang hadir dengan menawarkan sarana prasarana untuk wisatawan domestik maupun nin domesti. Dengan berbekelnya sumber daya manusia (SDM) yang berkualitas, Grand Cempaka Puncak Bogor menyajikan keutamaan dalam hal pelayanan yang ramah dengan sentuhan yang baik sehingga memberikan nilai tambah bagi pelanggan dengan tujuan menciptakan loyalitas.

Pendapatan perusahaan yang berada dalam taraf sehat selama beberapa tahun ini, menjadi bukti bahwa Grand Cempaka Hotel Bogor memiliki kekuatan dalam memikat hati para calon konsumen.

Analisis yang digunakan dengan cara hasil wawancara, hasil lapangan, dengan pihak sales promotion, dengan cara mereduksi data dari hasil wawancara peneliti dengan pihak SPS, dengan menganalisis peneliti mengkaitkan daripenyajian data tersebut hasil analisis tersebut sebagai berikut

1. Komunikasi personal di lakakukan oleh sales promotion eksekutif Grand Cempaka Puncak Bogor.Metode ini membantu penyebaran produk jasa yang akan di promosikan hingga menjangkau konsumen yang melakukan kontak langsung dengan penjualan langsung .SPS Melakukan promosi dengan menggunakan dua proses komunikasi yaitu primer dan sekunder. Proses primer adalah proses penyampaian pikiran dan perasaan antara komunikator dan komunikan dengan menggunakan simbol sebagai media, seperti alat bantu yang digunakan sales promotion eksekutif, seperti media brosur agar membantu padaa saat promosi. Promosi seperti produk jasa unggulan hotel seperti bungalow dan kamar hotel serta food and bafarange yang disediakan di Grand Cempaka Hotel Puncak Bogor, kepada calon konsumen. Penawaran discon promosi oleh sales promotion eksekutif langsung kepada calon konsumen. Hal ini membuat calon-calon konsumen tertarik dan berminat untuk memilih Grand Cempaka Hotel sebagai pilihan utama untuk berlibur bersama keluarga dan sebagai pilihan untuk event lainya, seperti acara pertemuan kantor dan acara family gathering. Berdasarkan observasi yang telah dilakukkan peneliti bahwa Grand Cempaka Hotel Puncak Bogor sudah memotivasi dan membujuk dengan cara mempromosikan fasilitas yang ada didalam hotel, serta menawarkan fasilitas produk hotel guna menarik calon calon konsumen menggunakan jasa hotel. hanya mengandalkan Marketing Grand Cempaka Hotel Puncak Bogor, memberikan penawaran dengan harga (Price)yang beragam. Grand Cempaka Hotel Puncak Bogor juga memberikan potongan harga untuk hari-hari besar seperti hari libur (weekand) hari libur nasional serta potongan harga untuk pemesanan paket large.

2. Penyajian produk salah satu bagian darimetode promosi direct selling di Grand Cempaka Puncak Bogor. Penyajian produk memperkenalkan fasilitas yang ada di Grand Cempaka Puncak Bogor seperti bungalaow dan room serta sarana bermain dan fasilitas lainya yang ada di Grand Cempaka Puncak Bogor, hal ini agar berupaya 
konsumen lebih termotivasi untuk masuk dan memahami informasi yang disajikan oleh sales promotion Grand Cempaka Puncak Bogor.4P yaitu mengenalkan produk yang ada di Grand Cempaka Puncak Bogor. Selanjutnya promotion yang dilakukan oleh sales promotion eksekutif melalui direct selling kepada calon calon konsumen, SPS juga menggunakan media komunikasi berupa brosur Grand Cempaka Hotel Puncak Bogor untuk lebih menarik minat caloncalon konsumen menggunakan jasa hotel.

3. Kecepatan promosi. Grand Cempaka Puncak Bogor melakukan promosi melalui direct selling dengan menggunakan kecepatan promosi hal ini agar mudah dipahami oleh konsumen, sebagian konsumen masih beriontrasi pada kepuasaan yang begitu cepat dirasakan ketimbang yang ditunda. Sangat berpengaruh lebih tinggi untuk paling tidak dicoba oleh konsumen hotel, pada proses promosi melalui direct selling yang dilakukan oleh sales promotion eksekutif Grand Cempaka Bogor.Serta membujuk calon konsumen, dan membuat calon konsumen potensial menyadari atas keberadaan produk jasa yang ditawarkan oleh Grand Cempaka Puncak Bogor.Grand Cempaka Hotel Puncak Bogor, melakukan promosi melalui direct selling untuk meminimalisir pengeluaran biaya promosi dan mempermudah mempermudah calon calon konsumen dalam menggunakan jasa penginapan di Grand Cempaka Hotel Puncak Bogor, dengan promosi direct selling calon konsumen juga meningkat dari pada menggunakan jenis promosi lainya. Hal ini bahwa promosi melalui direct sellingmemudahkan calon konsumen karena menyampaikan informasi dengan cepat mengenai Grand Cempaka Hotel Puncak Bogor, sehingga jelas dan mudah memahaminya.

4. Mayoritas awal. Promosi direct selling Grand Cempaka Puncak Bogor sebagai sales promotion eksekutif menghindari resiko pada saat pembelian itu berlangsung resiko tersebut seperti melebihi kapasitas sehingga fasilitas mudah dengan rusak. Kerusakan yang terjadi di akibatkan oleh konsumen yang tidak menjaga fasilitas di dalam lingkungan hotel tersebut

5. Grand Cempaka Puncak Bogor melakukan promotion di tempat (place) di dalam ruangan marketing Grand Cempaka Hotel, terletak dilokasi yang startegis dan asri membuat calon konsumen tertarik menggunakan jasa hotel hal ini juga diungkapkan oleh salah satu informan yaitu calon konsumen Grand Cempaka Hotel Puncak dengan tempatnya strategis ke jalan raya dan dekat dengan tempat wisata dikawasan puncak, dan juga dekat dengan tempat berbelanjaan lainya, hal ini saya tertarik menggunakan jasa hotel Grand Cempaka Puncak Bogor .

6. 5.Mayoritas akhir. Dilakukan sales promotion Grand Cempaka Puncak Bogor melakukan kesepakatan pembelian dan berhati-hati agar proses Kegiatan yang dilakukan pihak sales promotion eksekutif cukup menarik, sehingga untuk mempertahankan apa yang telah dilakukan oleh Grand Cempaka Hotel Puncak mengenai promosi melalui direct selling yang dilakukan sales promotion eksekutuf. Hal ini menarik bagicalon konsumen, calon konsumen mencari keunggulan hotel, ketika pembeliaan menggunakan jasa hotel. Promosi dilakukan di Grand Cempaka Hotel hal tersebut sangat menguntungkan bagi pihak perusahaan karena calon konsumen lebih banyak menggunakan jasa Grand Cempaka Hotel Puncak Bogor, dibandingkan Promosi melalui iklan atau media surat kabar. Promosi melalui direct sellingtidak begitu cukup besar dalam pengeluaran modal saat promosi

Dari hasil penelitian terlihat bahwa promosi melalui direct selling dalam meningkatkan minat konsumen 
menggunakan jasa hotel, studi dilakukan di Grand Cempaka Puncak Bogor, dikalangan calon konsumencukup baik.Metode promosi ini sangat berpengaruh karena dengan adanya direct selling sangat baik dalam meningkatkan minat konsumen menggunakan jasa hotel.

Promosi atau tindakan untuk menginformasikan kepada calon konsumen, merupakan bagian sangat penting didalam usaha untuk memperoleh public opinion yang menguntungkan. Dalam tahap ini bagian promosi dan marketing perlu sekali mengetahui proses direct selling guna mengetahuimetode Promosi direct selling, dan cita-cita organisasi, lembaga, atau perusahaan.

Komunikasi pemasaran memegang peranan sangat penting dalam keberhasilan penjualan suatu perusahaan, pada tingkat dasar, komunikasi berguna untuk menyampaikan informasi kepada publik. Dalam komunikasi pemasaran sama halnya dengan promosi yaitu merupakan usaha untuk menyampaiakan pesan kepada publik atau mempengaruhi dan membujuk serta mengingatkan calon-calon konsumen, dan membuat calon konsumen potensial menyadari atas keberhasilan atas keberadaan produk jasa yang ditawarkan dan berusaha membujuk calon-calon konsumen, dan membuat calon konsumen potensial menyadari atas keberadaan produk jasa yang ditawarkan dan berusaha membujuk agar berhasrat masuk kedalam proses pertukaran (Sutisna:2002)

Dari penelitian ini mengambil metode promosi direct selling menurut David promosi adalah suatu tindakan untuk menginformasikan kepada calon konsumen untuk mengenalkan produk jasa yang dipasarkan oleh pihak sales promotion, dan meyakini para pembeli untuk membeli barang produk jasa perusahaanya. Direct selling adalah penjualan langsung secara face to face, suatu proses anatara pihak calon konsumen atau komunikator akan tetapi dapat didukung dengan media atau seseorang, sebagai sales promotion atau mediator perusahaan. Dengan penelitian inidirect selling yang dilakukan seorang sales promotin eksekutifditujukan untuk mengubah pola pikir serta presepsi calon konsumen guna menigkatkan minat calon konsumen hotel, dan dimungkinkan pula akan terpengaruh pada tingkah lakunya.

\section{Promosi Melalui Direct Selling Dalam Meningkatkan Minat Calon Konsumen Menggunakan Jasa Hotel}

Pada metode promosi melalui direct selling dalam meningkatkan minat calon konsumen menggunakan jasa hotel studi pada Grand Cempaka Puncak Bogor. Sales promotion eksekutif melakukan promosi dengan menggunakan dua proses komunikasi yaitu primer dan sekunder. Proses primer adalah proses penyampaian pikiran dan perasaan antara komunikator dan komunikan dengan menggunakan simbol sebagai media, seperti alat bantu yang digunakan sales promotion eksekutif, seperti media brosur, sales promotion eksekutif melakukan promosi dengan cara membujuk untuk meyakinkan calon konsumen dalam hal meyakinkan serta membujuk yaitu dengan cara menawarkan produk jasa unggulan seperti fasilitas bungalow atau room dari class eksekutif sampai class busines, SPS tak lupa mempersentasikan keindahan viewnya Grand Cempaka Puncak Bogor, bagi sales promotion eksekutif mempromosikan tawaran discon yang ada di Grand Cempaka Puncak Bogor, discon yang ditawarkan kepada calon konsumen merupaka discon special deals yaitu discon yang di adakan setiap hari libur seperti weekand, discon ini berupa potongan harga bungalow serta room, dan tiga fasiliatas yang diberikan gratis saat mendapatkan discon seperti fasilitas Water boom, SPA, makanan dan minuman di pagi hari. Proses sekunder adalah proses penyampaian pesan oleh seseorang kepada orang lain dengan menggunakan alat bantu yang berupa brosur sebagai alat pembantu bagi mediator perusahaan. 
Metode Promosi melalui direct selling Grand Cempaka menggunakan kecepatan promosi agar lebih cepat dipahami oleh calon konsumen hotel, karena sebagai calon konsumen hotel masih bereontasi pada kepuaasan dengan cepat cendrung berkemungkinan lebih tinggi. Hal ini Grand Cempaka Puncak Bogor dalam meningkatkan minat konsumen menggunakan jasa hotel terbukti dengan adanya metode promosi direct selling seperti kecepatan promosi. SPS melakukan kecepatan promosi dengan cara kodalam menggunakan jasa hotel, kmunikasi langsung atau face to face sangat baik digunakan melalui kecepatan promosi agar tidak memeperhambat pembelian antara SPS dengan calon konsumen. Bagi SPS minat Konsumen berpengaruh besar terhadap prilaku dan minat sumber motivasi yang akan mengarahkan calon konsumen dalam melakukan apa yang mereka lakukan. Hal ini menigkatkan konsumen menggunakan jasa hotel.

Mayoritas awal hal ini untuk menghindari risiko dalam promosi maupun pembeliaan.Risiko tersebut berupa kesalahan yang terjadi dilakukan oleh pihak sales promotion karena dengan adanya gangguan dalam menginformasikan isi pesan serta ganguan yang diperoleh oleh pihak calon konsumen seperti mengcancel saat pembeliaan tersebut.

Mayoritas akhir metode tersebut untuk melihat bahwa saat melakukan pembelian terhadap SPS . Sales promotion harus berhati-hati agar calon konsumen tidak pindah ke merk lain, SPS harus meyakini calon konsumen agar menjadi konsumen Grand Cempaka Puncak Bogor sehingga metode promosi direct selling seperti mayoritas akhir berpengaruh untuk menigkatkan minat konsumen menggunakan jasa hotel.

SPS melakukan metode promosi terdapat lima komponen komunikasi untuk meyakini dan mencari calon calon konsumen secara cepat serta memberikan saran dan syarat permintaan calon konsumen. Hal ini sales promotion eksekutif penting melakukan komponen komunikasi seperti:

penyampaan isi pesan kepada calon calon konsumen untuk membujuk calon calon konsumen,sehingga dapat menciptakan permintaan terhadapcalon konsumen sehingga menjadi calon konsumen Grand Cempaka Hotel Puncak Bogor.

Pesan yang dikirim oleh salespromotion eksekutif sebagai komunikan harus jelas dalam melakukan pembujukan agar calon konsumen yakin sehingga menggunakan produk jasa hotel tersebut, dengan memberikan saran dan syarat penjualan didalam isi pesan tersebut.

Sales promotion eksekutif dan marketing melakukan promosi tujuanya untuk menginformasikan kepada calon konsumen untuk mengenalkan produk jasa yang dipasarkan oleh pihak perusahaan. Akan tetapi pesan tersebut harus tau bagaimana pesan itu disampaikan, Grand Cempaka Hotel Puncak menyampaikan pesan dengan menggunakan mediator perusahaan yaitu Salespromotion eksekutif,dan alat pembantu lainya seperti brosur untuk memperlancar melakukan promosi melalui direct selling sehingga hasilnya memuaskan pagi komunikan dan komunikator saat melakukan penjualan. Pihak Marketing menjawab secara langsung guna menjawab keinginan para calon-calon konsumen dan keinginan pasar tersebut.

Penerimaan Pesan, Pihak sales promotion eksekutif harus baik dan benar dalam menyampaikan isi pesan terhadap komunikan, sehingga komunikan menerima isi pesan yang baik apa yang disampaiakan oleh komunikator tersebut, sehingga tidak menimbulkan banyak gangguan atau hambatan komunikasi yang dilakukan sales promotion eksekutif. akan tetapi ada beberapa hambatan tetapi tidak mempengaruhi dalam penjualan tersebut.

Grand Cempaka Hotel Puncak Bogor, Pihak sales promotion eksekutif dan calon calon konsumen akan menimbulkan 
feedback dan efect terhadapat satu sama lain, dan menguntungkan bagi kedua belah pihak. Guna mencari calon-calon konsumen yang lebih banyak dan luas.

Promotion dilakukan di tempat Grand Cempaka Hotel Puncak Bogor, atau diberbagai tempat pertemuan lainya seperti ada perjanjian dahulu oleh pihak calon calon konsumen. Promosi direct selling merupakan kekuatan Grand Cempaka Hotel untuk memasarkan dan mejual jasa hotel tersebut. Pengaruh besar calon konsumen berminat menggunakan jasa hotel tersebut karena adanya promosi melalui direct selling karena dengan promosi ini sangat memudahkan calon konsumen sehingga calon konsumen lebih cepat membeli produk jasa yang ditawarkan sales promotion eksekutifGrand Cempaka Hotel Puncak Bogor, selain itu startegi penyampaian pesan yang di sampaikan oleh pihak sale promotion eksekutifsangat baik sehingga calon konsumen terbujuk dan yakin ingin membeli produk jasa hotel tersebut.

Selain membeli calon konsumen tertarik dalam penyampaiaan informasi secara terperinci dalam mempersentasikan fasilitas yang ada didalam Grand Cempaka Puncak Bogor.sehingga calon konsumen lebih puas dan nyaman dalam menggunakan jasa hotel.

Dari observasi yang dilakukan oleh peneliti para karyawan Grand Cempaka Puncak Bogor, khususnya divisi marketing sangat mementingkan kerjasama. Dengan sesama devisi marketing mereka tidak segan-segan membantu satu sama lain walaupun pegangan pekerjaan mereka berbeda akan tetapi tujuan marketing adalah mencari calon konsumen seluas mungkin dan memberikan kepuasan dalam pelayanan yang diberikan Grand Cempaka Hotel.hal itu agar Metode promosi melalui direct selling lebih berkembang dan menjadi suatu unggulan bagi perusahaan Grand Cempaka Hotel Puncak Bogor, guna menjaga keeksistensianya sebagai hotel yang memiliki metode promosi melalui direct selling, dan terus ditingkatkan oleh pihak marketing khususnya sales promotion eksekutif perusahaan.Grand Cempaka Puncak Bogor bahwa promosi melalui Grand Cempaka Hotel sudah efisien, hal ini terbukti dari aspek metode dan komponen promosi direct selling, metode promosi direct selling mudah dan cepat dalam membujuk calon konsumen sehingga dapat menarik minat calon konsumen untuk menggunakan jasa hotel.

Selain itu Grand Cempaka Hotel menawarkan fasilitas yang nyaman gunamenarik calon konsumen untuk menjadi pelanggan tetap,sehingga promosi ini harus selalu ditingkatkan dalam jangka panjang. Metodepromosi melalui direct selling selalu menjadi unggulan bagi Grand Cempaka Hotel Puncak Bogor,oleh karena itu direct sellingselalu menjadi program untuk karyawan khususnya bagi divisi marketing agar mampu mencari pangsa pasar yang seluas luasnya.Akan tetapi adanya noise saat promosi direct selling pada saat melakukan promosi melalui direct selling hambatan yang di maksud seperti SPS kurang fokus dan teliti saat promosi dilakukan dengan calon konsumen hotel. Hal ini dikarenakan kurangnya SDM pada divisi marketing sehinga mempengaruhi efek besar, akan terjadi menghasilkan pekerjaan yang tidak berkualitas dan menghambat pekerjaan.sehingga calon konsumen menunggu antrian pada waktu mempromosikan produk jasa yang ada di Grand Cempaka Puncak Bogor.

Tempat yang asri dan nyaman ketika melakukan promosi melalui direct selling digunakan ketika pertemuan calon konsumen dengan sales promotion eksekutifRuangan yang nyaman bersih salah satu tempat melakukan promosi melalui direct selling, konsumen melakukan pembelian diruangan tersebut, ketika konsumen ingin berputar-putar melihat keasrian dan fasilitas Grand Cempaka Puncak Bogor sales promotion eksekutif akan membawa calon konsumen dengan mengguanakan mobil wara-wiri promosi, sehingga calon konsumen lebih nyaman. 


\section{KESIMPULAN DAN IMPLEMENTASI}

\section{Kesimpulan}

Grand Cempaka Hotel melakukan metode promosi melalui direct selling selalu berusaha menghadirkan kebutuhan yang diinginkan oleh konsumen. Grand Cempaka Hotel Puncak Bogor selalu memposisikan dirinya sebagai hotel atau resort yang paling asri dan bersih sehingga membuat konsumen lebih nyaman, selalu mampu memenuhi kebutuhan dan keinginan konsumennya. Menghadirkan keunikan dan keunggulan yang ada di Grand Cempaka Hotel, melayani konsumen dengan baik selalu dilakukan oleh segenap karyawan Grand Cempaka Hotel Puncak Bogor.

Metode promosi yang dilakukan Grand Cempaka Hotel Puncak Bogor sudah efektif yaitu komunikasi dari mulut kemulut dan melalui brosur dalam menawarkan fasilitas Grand Cempaka Hotel Puncak Bogor. Penyajian Produk Grand Cempaka Hotel memperkenalkan fasilitas hotel dengan melalui promosi Direct Selling yaitu penjualan langsung melalui komunikasi personal oleh sales kepada calon pembeli.

\section{Implementasi}

Berdasarkan hasil penelitiaan yang dilakukan, peneliti mencoba memberikan beberapa saran kepada Grand Cempaka Hotel Puncak Bogor, dalam mempromosikan melalui direct selling dalam meningkatkan minat konsumen menggunakan jasa hotel Grand Cempaka Puncak Bogor:

1. Mempengaruhi metode promosi (direct selling) terutama dalam memperkenalkan Grand Cempaka Hotel Puncak Bogor ke khalayak luas agar lebih tepat sasaran karena masih ada sebagian calon konsumen yang tidak mengetahui Grand Cempaka Hotel Puncak Bogor.
2. Menambah Sumber Daya Manusia (SDM) untuk divisi Sales section, upaya divisi tersebut agar membantu saat melakukan promotion bersama sales promotion eksekutif, agar menghasilkan pekerjaan yang berkualitas dan tidak menghambat pekerjaan.

3. Terus meningkatkan intensitas kegiatan direct selling. Kegiatan direct selling harus lebih maksimal agar tetap menjaga intergeritas Grand Cempaka Hotel menjadi hotel bintang tiga nomor satu di kawasan kota wisata Puncak Bogor.

4. Tetap meningkatkan kualitas dan kuantitas pelayanan terhadap seruruh klien setia Grand Cempaka Hotel Puncak Bogor. Sehingga diharapkan dapat lebih memperoleh loyalitas stakeholder maupun pengunjung Grand Cempaka Hotel Puncak Bogor. Kualitas yang dimaksud fasilitas produk hotel, serta kuantitas pelayanan yang excelent terhadap konsumen Grand Cempaka Puncak Bogor.

5. Tetap sales promotion eksekutif selalu meningkatkan Minat Konsumen Hotel dalam mempromosikannya melalui direct selling agar terjaga keeksistensianya. Pada perkembanganya zaman, direct selling akan bersaing oleh media-media yang lebih cepat dan canggih prosesnya, sehingga dimungkinkan direct selling tidak kalah saing dengan promosi media lainya seperti iklan yang di tampilkan di media cetak maupun elektoronik. 


\section{DAFTAR PUSTAKA}

Alma B. 2005. Manajemen Pemasaran dan Jasa. Bandung : Alafabeta.

Bagyono. 2005.Pariwisata dan Perhotelan. Bandung: Alfabeta.

David W. 2005. Startegi Pemasaran Direck Selling. Jakarta : Erlangga.

De.Wever L. 2001. Seni menggunakan direct selling dan marketing. Jakarta : PT Elex media komporindo.

Dewantri.2014. Strategi Promosi Melalui Promosi Direct Selling Cafe Burger Lover Me dalam Meningkatkan Jumlah Konsumen. [Skripsi]. Yogyakarta: Fakultas Ilmu Sosial Ilmu Politik Universitas Muhamadiyah Jogja.

Dwi N. 2014. Strategi Promosi Direct Selling dalam meningkatkan hotel Horison bekasi Terhadap jumlah pengunjung. [Skripsi]. Semarang: Fakultas Ilmu Sosial Ilmu Politik Univeritas Islam Negeri Semarang.

Efendy OU. 2006. Ilmu komunikasi teori dan pratek. Bandung: PT. Rosdakarya.

Kotler P, kevin LK. 1999. Manajemen pemasaran Edisi 12 jilid IndeksPrintice hall. Jakarta.

Mulyana D. 2005. Ilmu Komunikasi: suatu pengantar . Bandung: PT. Remaja Rosdakarya.

Rangkuti F. 2009. Startegi Promosi Komunikasi yang kereatif dan Analisis Kasus intergerty marketing comunication. Jakarta : PT. Gramedia Pustaka Utama.

Sugiono. 2010. Metode Penelitian Kualitatif. Bandung: Alfabeta.
Sukmadinata NS. 2011. Metode Penelitan Kualitatif. Bandung . ID:PT. Remaja Rosdakarya.

Suyantono D. 2015. Perilaku Konsumen dan Pemasaran. Jakarta: CAPS.

Tauhuromaat M. 2015. Bauran Promosi dalam Meningkatkan Jumlah Pemasang Iklan. [Skripsi]. Bandung: . Fakultas Ilmu Sosial Ilmu Politik Universitas Islam Negeri Sunan Kalijaga.

Yasir S. 2009. Intim Dengan Pelanggan Strategi Bersaing Dengan Konsumen . Jakarta : Lembaga Penerbit Universitas Indonesia.

Yoeti OK. 2004. Strategi Pemasaran Hotel. Jakrata : Gramedia.

\section{INTERNET}

Erinta, 2013 Info Direct selling dan Hotel. Diakses pada 9 Desember 2016 (http://www.media.com.co.id/tag/pe ngerianhoteldandirectselling).

Maya, 2014 Pengertian Promosi. Diakses pada 7 Desember 2016 (http://www.shoop.back.com.co.id/ta $\mathrm{g} /$ pengertianpromosi).

Pengertian Direct Selling. 2015. Diaskes pada 2 Desember 2016 (http://www.shoop.media.com.co.id.t ag/directderictselling. 